\title{
The threatened birds of Ambatovaky Special Reserve, Madagascar
}

\author{
P. M. THOMPSON and M. I. EVANS
}

\begin{abstract}
Summary
Ambatovaky Special Reserve was created in 1956 and is the largest lowland rainforest reserve in Madagascar, comprising more than half of the total area of this habitat represented in the country's protected area system, yet there are no measures in place actively to protect it, due to its remoteness and a lack of funds. This study in FebruaryMarch 1990, part of the first faunal survey to be undertaken in the reserve, found seven threatened, five near-threatened and two other localized bird species. In itself this would make the reserve an important site for conservation. However, three of the finds are of particular note: Ambatovaky is one of only two known sites for the Red-tailed Newtonia Newtonia fanovanae which was rediscovered in 1989; a dead Madagascar Serpent-eagle Eutriorchis astur was found - the first specimen since 1930 of one of the world's rarest raptors; and the White-breasted Mesite Mesitornis variegata was discovered in rainforest where Brown Mesite $M$. unicolor was also present, this being the only known case of sympatry within the endemic Mesitornithidae family. Shifting cultivation threatens the habitat of all these species and an integrated plan for conservation and sustainable development for the local people is urgently needed.
\end{abstract}

La Réserve Spéciale d'Ambatovaky a été crée en 1956 et représente la plus grande réserve de forêt pluviale à basse altitude de Madagascar. Elle couvre plus de la moitié de la superficie totale de cet habitat, intégrée au système de zones protégées du pays. Pourtant, à cause de l'isolement géographique et du manque de ressources financières, aucune mesure de protection active n'a pu être encore mise en place. Cette étude accomplie en février-mars 1990, et faisant partie de la première recherche menée sur la faune de cette réserve, a permis de découvrir sept espèces d'oiseaux menacées, cinq espèces presque menacées et deux espèces locales. En soi, cela suffirait pour donner à cette réserve le statut de site important pour la conservation. Cependant, trois de ces découvertes méritent une attention particulière: Ambatovaky est l'un des deux seuls sites connus abritant la Newtonia fanovanae qui a été redécouverte en 1989; un aigle-autour de Madagascar, l'Eutriorchis astur a été trouvé mort - le premier spécimen depuis 1930 de l'un des rapaces les plus rares au monde; et le Mesitornis variegata, découvert dans la forêt pluviale où le Mesitornis unicolor était également présent, ceci représentant le seul cas connu de sympatrie à l'intérieur de la famille endémique des Mesitornithidae. L'extension des cultures agricoles menace l'habitat de toutes ces espèces, et il est urgent d'établir un plan de conservation et de développement pour la population locale compatible avec la conservation des ressources naturelles. 


\section{Introduction}

Madagascar is regarded as one of the world's prime targets for conservation efforts because of the high level of endemism among most of its faunal groups and the severe human pressure on natural habitats, in particular the extensive clearance of eastern rainforests for shifting cultivation (tavy). It has been estimated that between 1950 and 1985 half of these rainforests disappeared, at a rate of 111,000 ha per year (Green and Sussman 1990). Most of the remaining rainforest is in areas of low population density - often on steeper slopes. These eastern forests contain the greatest biodiversity on the island (see Jenkins 1987).

Madagascar's birds have been relatively well studied compared with the island's other faunal groups, although much remains to be discovered. Status and distribution were reviewed by Rand (1936), Benson et al. (1976-1977), Langrand (1990) and, for endemic species, Dee (1986); these authors showed that a number of species are scarce, known from scattered localities, or simply little known. Endemic forest-dependent species are of particular concern given the extent of deforestation. Out of 28 bird species in Madagascar categorized as "threatened" in the ICBP/IUCN African Bird Red Data Book, 13 are rainforest species (Collar and Stuart 1985).

Ambatovaky Special Reserve is the largest lowland rainforest reserve in Madagascar. It was created by presidential decree in 1956 and, out of a total area of 60,050 ha, 51,050 ha $(85 \%)$ is reported by Nicoll and Langrand (1989) to be in the "Eastern Domain" (or lowland rainforest), representing $54 \%$ of the rainforest of this type within the protected area network. Prior to the survey reported here virtually nothing was known about the reserve, except for satellite images indicating that large areas of forest still existed (G. Green in Nicoll and Langrand 1989). Moreover, Ambatovaky was an important unsurveyed link in the ornithology of the eastern rainforests, since it lies part-way between two areas (also reserves) where ornithological surveys have been carried out in recent years (Thompson et al. 1987, Safford and Duckworth 1990) and for which past records existed (see Figure 1). However, the areas of lower elevation Eastern Domain forest are much larger in Ambatovaky than in the mainly mid-altitude forest of "Sihanaka Forest" and Réserve Naturelle Intégrale (RNI) 3 (Zahamena) $70 \mathrm{~km}$ to the south, or than in RNI 12 (Marojejy) $200 \mathrm{~km}$ to the north, which has only 12,030 ha of Eastern Domain or lowland rainforest (Nicoll and Langrand 1989). Consequently Nicoll and Langrand (1989) listed the reserve as a priority area for a baseline survey.

A revised reserve map was compiled for this study based on the 1:50,000 topographic maps published by Institut Géographique National (Paris Centre à Madagascar) and Foiben-Taosarintanin'i Madagasikara in 1972 and 1977 (which were based on aerial photographs from 1957, checked on the ground between 1969 and 1974) and the reserve boundary from the 1956 sketch map prepared when the reserve was declared (Direction des Eaux et Forêts files). Figure 1 is based on these sources. The reserve lies between $16^{\circ} 57^{\prime}$ and $16^{\circ} 36^{\prime} \mathrm{S}$ and $49^{\circ} \mathrm{O} 4^{\prime}$ and $49^{\circ} 25^{\prime} \mathrm{E}$. The area of the reserve was re-estimated from the new map as approximately $61,500 \mathrm{ha}$, in very close agreement with the original estimates. However, ground surveys as part of this study revealed that much of the southeastern part of the reserve below $500 \mathrm{~m}$ is now deforested. 


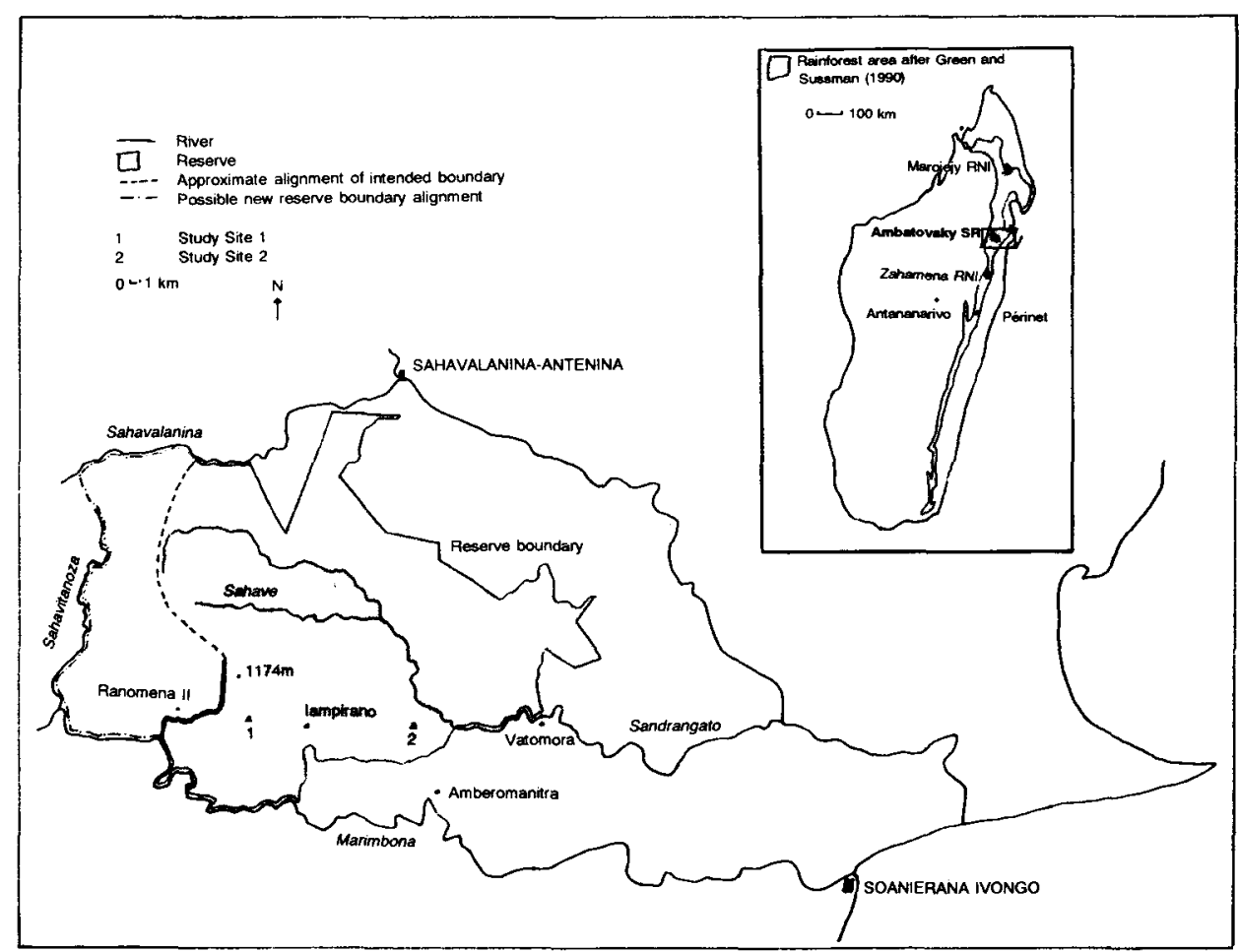

Figure 1. Ambatovaky Special Reserve. Inset: Madagascar showing rainforest and reserves mentioned in the text.

The aims of the ornithological survey were to compile a species list for the reserve, with particular emphasis on searching for and obtaining information on threatened and near-threatened species. This information is summarized here; Thompson and Evans (1991a) give details of all the 83 species recorded in the reserve (along with 12 others reported by local people).

\section{Methods}

\section{General}

Birds were surveyed by direct opportunistic observation, principally by the two authors. Tape-recording and playback was tried but did not prove very successful, probably because the fieldwork took place in the immediate post-breeding season. No mist-netting was undertaken as this had shown very low capture rates in previous surveys (Thompson et al. 1987, Safford and Duckworth 1990). Intensive surveys were made at two sites, described below and chosen because of the generally intact and extensive nature of their forests, and their differing altitudes, amongst other reasons.

Discussions with local people showed that they were very knowledgeable about the birds of the area, for example recognizing the ground-rollers Brachy- 
pteraciidae present. However, some identifications were unclear due to loss of nuances in translation, and because the boundary of the reserve is unknown to local people their input was of limited use in determining the certain occurrence of species within the reserve.

\section{Site one (centred on $16^{\circ} 51^{\prime} S 49^{\circ} 08^{\prime} E$ )}

This study area was based at a camp about $6 \mathrm{~km}$ west of Iampirano village, by the Iampirano river at about $530 \mathrm{~m}$ altitude. Surveys took place from 5 February to 1 March 1990 . The camp was in a valley bottom in primary lowland rainforest (we follow White's [1983] terms and definitions when referring to forest types) near the limit of the patches of regenerating and grazed tavy which extend up the valley from Iampirano village. The area of detailed studies covered about $6 \mathrm{~km}^{2}$. Below about $700 \mathrm{~m}$ was lowland primary forest with a high canopy (over $30 \mathrm{~m}$ ) and in the valley bottoms relatively little undergrowth. Above this a ridge trail and slopes from about 700 to $950 \mathrm{~m}$ were regularly visited, and comprised primary moist montane forest with a lower canopy $(20-25 \mathrm{~m})$ and more undergrowth; the low starting altitude for this habitat is due to the exposed nature of ridge-tops. At about $950 \mathrm{~m}$ there was a relatively sudden transition to sclerophyllous montane forest extending to the highest summits in the reserve at approximately $1,100-1,200 \mathrm{~m}$. An extension to an existing trail was cut by the expedition to a peak just south of the main Ambatovaky peak of $1,174 \mathrm{~m}$. This sclerophyllous montane forest had a lower canopy of about 10-15 m (down to 4$5 \mathrm{~m}$ on the summit) and dense undergrowth, with trees covered in mosses, lichens and epiphytes.

The long climb to the sclerophyllous montane forest area meant that relatively little time was spent in this zone, and no threatened bird species were found in the area, but it is possible that some species which prefer this habitat were missed. An altitude of $950 \mathrm{~m}$ is relatively low for the start of sclerophyllous montane forest, but in the section of the rainforest belt occupied by Ambatovaky there are no mountains above $1,200 \mathrm{~m}$, and therefore these low summits are relatively exposed, so the habitat zones are compressed and found at lower altitudes compared, for example, with Marojejy RNI (Safford and Duckworth 1990), an example of the Massenerhebung effect (see Whitmore 1984).

Hunting pressure on birds and other animals in this area is low and is a lesser threat than forest clearance; the trails are simple through-routes and do not have the anastomosing, wide-ranging pattern characteristic of heavily hunted areas. No lemur traps were found and none of the few people encountered was carrying hunting equipment or was accompanied by dogs. However, free-ranging cattle in abandoned agricultural clearings hinder the regrowth of forest in these areas. Local people also collect plants and wild honey from the forest.

\section{Site two (centred on $16^{\circ} 51^{\prime} S 49^{\circ} 16^{\prime} E$ )}

This study area was based around a camp approximately $6 \mathrm{~km}$ north of Amberomanitra, and about $2 \mathrm{~km}$ within the southern boundary of the reserve, in an area of tavy at about $380 \mathrm{~m}$ altitude by the Antsanavavy river. Immediately north of this river was a narrow band of secondary forest fringing primary lowland 
forest. Surveys took place between 4 and 25 March 1990. The study area comprised primary lowland forest over steep-sided ridges at $450-485 \mathrm{~m}$ and narrow valley bottoms at $340-400 \mathrm{~m}$. The valley bottom forests were similar to those at Site 1, although apparently better drained with a somewhat lighter, sandier soil, which was not as swampy and humus-rich. The ridges, although at low altitude, supported forest with a slightly lower canopy (up to $25 \mathrm{~m}$ ) and considerably more undergrowth than the valley bottoms. All of the threatened bird and lemur species found at this site occurred on these ridges but very few were recorded in the valley bottoms (Thompson and Evans 1991b). However, this may be an observational artefact so far as arboreal species are concerned since the understorey attracted birds and lemurs down from the canopy.

Observer activity was concentrated on a patch of about $4 \mathrm{~km}^{2}$, which comprised about half of the area in this altitudinal range within the reserve south of the Sandrangato river; a substantial part of the remainder of this zone is already degraded or cleared of forest. The team was able to work from a dense network of existing trails which provided access to isolated areas of current tavy.

Cattle, which were free-ranged in areas of tavy, did not penetrate more than $50 \mathrm{~m}$ into primary forest at this study site, but some areas of tavy (holding cattle) were found well within the forest on the slopes by the Sandrangato river. During the survey all of the active tavy in this part of the reserve was used for hill rice and maize, no tree crops appeared to have been planted, and buildings were only occupied during the growing season. Hunting pressure is relatively high in the area, each ridge trail had a number of lemur traps, and pigs, tenrecs and birds were also hunted with dogs and catapults. The hunting pressure resulted from the much higher population density bordering the study area compared with Site 1 .

\section{Results: species accounts}

During the two months of fieldwork seven threatened and five near-threatened bird species were discovered inside the reserve. In addition all four rainforest species identified by Langrand (1990) as particularly vulnerable because their ranges are restricted to the north-eastern rainforests were found to be relatively numerous (these include two species not listed as threatened or nearthreatened). This section details all relevant information collected for these 14 key species. English names are based on Langrand (1990), Dee (1986), and Benson (1981); species order follows Morony et al. (1975); scientific names follow Langrand (1990), except where stated otherwise in the text. Red Data Book status is based on Collar and Stuart (1985).

The only observation was of two on 21 March: disturbed from a flat area of sparsely vegetated forest floor in a part of Site 2 that was little visited by us. However, this species was reported by local people to be present but scarce and hunted in all areas visited. Control over hunting within the reserve would be particularly beneficial for this species, which is widely distributed in forests in 
east and west Madagascar, but is also intensively hunted (Keith et al. 1974, Langrand 1990).

On 24 February 1990, during a reconnaissance visit to the south-western extremity of the reserve, C. J. Raxworthy discovered the skeleton and feathers of a recently decomposed corpse of a large raptor while searching the leaf-litter for herpetofauna by the trail approximately 4-5 km east of Ranomena II in primary rainforest at about $650 \mathrm{~m}$. The skull and three wing feathers were collected, as the corpse could not be identified at the time. The material has since been taken to the U.K. where P. R. Colston of the Natural History Museum confirmed that it belongs to E. astur (see Raxworthy and Colston 1992).

This species has been considered to be one of the six rarest of birds of prey in the world (Langrand and Meyburg 1984), and is known from only 12 specimens collected in forests in the centre-east and north-east of Madagascar between 1874 and 1930 (Collar and Stuart 1985, Collar and Andrew 1988). Subsequently there has been only one documented sight record, from Marojejy RNI in 1988 (Sheldon and Duckworth 1990). The record from Ambatovaky is thus only the fourteenth documented, and the only specimen since 1930; the skull is the only one available for study and is deposited with the feathers at the Natural History Museum, Tring, U.K.

This species has always been regarded as a scarce and secretive bird of primary rainforest, and this record came from the widest band of primary rainforest traversed by the expedition, which spent three weeks in apparently identical rainforest at Site 1 without any indication of the species's presence. There is a chance that this bird had been killed by man since the corpse was found by a trail used regularly as a through-route by local people. This find provides a strong argument for expanding the Ambatovaky reserve westward to include the large area of extant primary rainforest above $600 \mathrm{~m}$ in this area, which must be assumed to contain a population of this species (which seems likely to live at very low densities and hence would benefit from the preservation of as large an area of primary rainforest as possible).

Near-threatened

Although none was recorded at Site 1 , this species was regularly recorded at Site 2 where it was the joint commonest bird of prey and was recorded on 13 days involving 17 or 18 separate records. On 5 March one was seen in display flight over the edge of the forest whilst a second was calling; subsequently this species was less obvious and may have been under-recorded, although it was still regularly heard. The survey took place at the end of the presumed breeding season (October-November: Langrand 1990) but the absence of calling at Site 1 compared with its obvious presence at Site 2 suggests that it might not be present or is much scarcer. This species hunts below the canopy, making detection difficult other than by its distinctive call. It seems likely that it hunts lemurs (Langrand 1990): when a large raptor, almost certainly this species, flew into a 
tree holding three brown lemurs Lemur fulvus they instantly stopped contact grunting and moved away.

Although this species is widespread in wooded areas, apart from in the south of the island, it appears to have been definitely recorded from rather few locations in the eastern rainforests (Dee 1986) and to be "fairly rare" (Langrand 1990).

On 17 and 21 March a pair of White-breasted Mesites were watched intensively in the reserve, on both occasions in an area only five minutes walk from Camp 2 just within primary rainforest (next to secondary forest or "savoka") at $350 \mathrm{~m}$ altitude at the base of a steep slope. Photographs were obtained and detailed descriptions made on 21 March. Both birds were quite approachable and on 21 March were watched from oghoo to 15 hoo. This area was along the main trail into the forest and was visited by each member of the team several times each day, thus the lack of records on other days is surprising. Virtually the only calls given were a low "cluck" alarm call. Evans and Raxworthy (in prep.) give further details of the observations.

This member of an endemic family was previously only known from four areas (Langrand 1990); Ankarafantsika (RNI 7) and Ampijoroa Forest Station (Collar and Stuart 1985); north-east of Morondava (Collar and Stuart 1985); Ankarana Special Reserve (Dee 1986, Hawkins et al. 1990); and Analamera (Langrand 1990). Three of these sites are reserves, and all are in western Madagascar where this species lives on the ground in dry forest with limited undergrowth. Despite the confused belief in the late nineteenth and early twentieth centuries that Brown and White-breasted Mesites were female and male respectively of the same species (Collar and Stuart 1985), there is no previous evidence of their ever being sympatric. Rainforest and deciduous forest in Madagascar are now separated by large areas of deforested land, with the possible exception of the north-west. This record is so unexpected and contrary to existing knowledge that it is impossible to predict whether the species may be found elsewhere in the eastern rainforest, but observers need now to be aware of the possibility of both species of mesite occurring in such habitat.

This record is thus the first from rainforest, and forms the first case of sympatry with Brown Mesite (which was recorded within 10 minutes' walk of the White-breasted Mesite site). This was one of only five endemic bird species listed by Langrand (1990) as restricted to the dry deciduous forests of the western domain or division of the western region. Even more remarkable is the fact that this area of Ambatovaky reserve is towards the eastern side of the widest block of extant rainforest in Madagascar: see maps in Green and Sussman (1990). Although in the same latitude range as the other known sites, Ambatovaky is one of the most distant sites from western deciduous forest. This rare species was found in the most threatened part of the reserve where improved protection is most urgently required. 
This secretive and cryptic species was only definitely noted at Site 2 on ridgetops at $400-450 \mathrm{~m}$, although a pair of birds very likely this species was noted at about $650 \mathrm{~m}$ at Site 1 . This species was recorded in twos - presumed pairs - with the exception of one apparently single bird (which, however, could easily have had a mate nearby). Locating this species was aided by its regular, though infrequent, contact calls (a distinctive sharp but low chicken-like "cluck" or "tschuk"). On 8 March a pair was seen followed by the apparently single bird about $2 \mathrm{~km}$ away, and on 20, 22 and 24 March single pairs were recorded. From the distribution of records we believe that at least four pairs must have been involved. At Site 2 compared with Site 1 there was more leaf-litter and undergrowth along the ridges, which may be a reason why this species, and other terrestrial birds, were only recorded at this second site.

The observations comprised two pairs which were foraging on ridge-tops and were disturbed by observers: one pair walked quickly down the ridge slope away from the observer, the second pair split up on either side of an infrequently used trail with one jerkily scuttling towards cover after first peering at the observer. A pair scuttled quickly and nervously across the main trail at the top of the slope above the White-breasted Mesite site, and not far away on a separate day a pair was heard making contact clucks as they foraged on the ridge slope (fleeting glimpses were obtained). The single bird was watched foraging by a stationary observer: it followed a deliberate but meandering course along the forest floor, its nervous movements (head and tail bobbing, particularly when in exposed situations) being reminiscent of both a rail Rallidae and a chicken. In all cases the white streak behind the eye was the most striking plumage feature.

It is not possible to say how scarce this species is in Ambatovaky, since it was only recorded when birds happened to cross trails in front of observers or were surprised on trails, or from quiet contact calls heard close to a trail (pairs kept contact by calling even when on either side of a trail). Steep slopes, dense undergrowth and the species's excellent camouflage and secrecy meant that it was never possible to follow birds for very long (twice they were suspected of freezing hidden for some time close to an observer before or after discovery). This is fortunate since the same trails are often used by potential hunters and their dogs. Ambatovaky lies within the range recorded for this species, the closest confirmed site being an old specimen from Mananara (Collar and Stuart 1985). Based on Langrand (1990) Ambatovaky is the fifth protected site where it has been recorded recently.

\section{Red-breasted Coua Coua serriana}

This species was only recorded at Site 2 with a total of ten sightings on six days in river valleys and on a gentle ridge slope, at approximately $375-450 \mathrm{~m}$. A fledged juvenile was seen with an adult on three separate days between 10 and 21 March. The juvenile was very approachable, even inquisitive, and was recorded begging for food from the adult. It was distinguished by orange-buff bars on the wing coverts, an untidy head without full feathering but with a 
reduced blue patch and some fleshy-grey skin, rather than the blue face patch of adults, and a pale reddish base to the bill. This species was almost always seen walking through undergrowth, the maximum perched height being $2 \mathrm{~m}$, and the adults were rather wary. The distinctive calling was only heard from 22 March onwards. Although this strictly terrestrial species is the most difficult of the rainforest couas to see, the lack of sight records (as with other terrestrial species) at Site 1 is puzzling, as is the lack of calling during most of the survey; postbreeding moult makes most birds shyer than normal and would presumably have been occurring at this time, however.

Ambatovaky is thus one of the few protected areas where this species has been found (Langrand 1990), and it may be fairly numerous at lower altitudes there. This species was regarded by Langrand (1990) as a key species restricted to the rainforests of the north-east, where it is known from the MasoalaMaroantsetra area, Marojejy RNI and the proposed Mananara Biosphere Reserve. There are few recent records south of Ambatovaky: a single record from Zahamena RNI (Thompson et al. 1987) and two from Analamazaotra-Périnet Special Reserve (Thompson and Buisson 1988, Safford and Duckworth 1990).

Short-legged Ground-roller Brachypteracias leptosomus

Rare

This species was only recorded at Site 2 along ridges at about $400-450 \mathrm{~m}$. There were seven records on six days: after one on 10 March all the others were during the period 18-25 March. This apparent change in abundance is inexplicable since observer effort was constant throughout the period and virtually no new areas were added to the study area after the first few days at Site 2. This pattern of records is the opposite of that shown by Scaly Ground-roller.

Typically birds were first flushed from perches at or just above head height (around $2-3 \mathrm{~m}$ ) in saplings and small trees, and flew only a short distance; they could then be observed for some time perched 2-5 $\mathrm{m}$ above the ground, and would allow a relatively close approach (to $5 \mathrm{~m}$ ) before flying down to the ground or disappearing into denser forest away from the trails. Birds watched for some time either preened or watched the observer or the surroundings. Prey items recorded were a $10 \mathrm{~cm}$ long millipede and a green mantis, but it was not possible to see where these were caught. One which perched in an understorey tree $10 \mathrm{~m}$ above the ground had almost completed its tail moult with all retrices new except for the outermost pair, which were still growing.

Home ranges may be relatively large since the encounter rate was low considering the amount of time spent along the trail system at Site 2. None of the records came from the damper valley bottoms, nor from the narrowest and most frequented ridge-top; forest on gentle ridge slopes or flatter areas of ridge-top appeared to be preferred, along with a relatively dense growth of saplings. The one exception was a bird which suddenly appeared in the middle of a mixedspecies feeding flock in the sub-canopy (perched on a large branch about $15 \mathrm{~m}$ above the ground), where it appeared to have chased one or more members of the flock (other species in which were: a pair of White-headed Vangas Leptopterus viridis, one juvenile Helmetbird Euryceros prevostii, one Bernier's Vanga Oriolia bernieri, one Blue Vanga Cyanolanius madagascarinus and one Crested Drongo Dicrurus forficatus). 
This species does not appear to be common anywhere (Collar and Stuart 1985, Langrand 1990), so Ambatovaky is an important addition to the list of protected areas harbouring it. Unfortunately the area of primary forest where it was found regularly is more immediately threatened with destruction by tavy than most other parts of the reserve.

Only recorded at Site 2 between 6 and 15 March, when there were 14 observations on seven days. However, there were additional possible sightings at Site 1 on 22 February, and at Site 2 on 7 March. It was thus regularly seen only during the first half of fieldwork at Site 2 (when it did not appear uncommon), whereas all but one record of Short-legged Ground-roller came from the second half of the time there. It is possible that local movements away from the study area occurred, since as March 1990 progressed the weather became increasingly less rainy and the birds' feeding habitat (leaf-litter and bare earth of the groundsurface) accordingly became drier (on exposed ridges first and in sheltered hollows and valley bottoms last); as a consequence, the moisture-loving invertebrate prey species which dwell in this habitat are likely to have become less available to the birds. Initial records came from ridge-tops, only during or after heavy rain, but as March progressed they came increasingly from slopes and valley bottoms. Also less time was spent in valley bottoms at Site 2 after 11 March. Birds were seen between approximately 350 and $450 \mathrm{~m}$ altitude, always on the ground or on fallen logs up to $1 \mathrm{~m}$ above the ground, except for one record of a roosting pair, which were perched $3 \mathrm{~m}$ up in an understorey tree at dusk.

On several occasions birds proved very confiding, permitting a close approach (down to $4 \mathrm{~m}$ ) and extended observation for up to 45 minutes. At the closest ranges, birds turned to face the observer, sometimes even approaching up to $1 \mathrm{~m}$ closer, and bobbed with tail spread and raised to show the blue patches at the tail base and terminal blue-green band, while making a soft, quiet, growling hissing call (a sign of excitement: Langrand 1990); if nervous, birds might then crouch low and scuttle several metres away, rather than flying. When birds were flushed at close range without warning, they would fly off directly in a shallow arc over the ground vegetation, only rising $1-2 \mathrm{~m}$ above the ground and travelling only 10-30 $\mathrm{m}$ distance, with noisily whirring wings. General behaviour involved foraging by hopping and running on the ground and turning over leaflitter with the bill, and running along logs. One bird, watched feeding for approximately one hour on the moist exposed mud of the main trail at Site 2, caught a cricket and three small unidentified invertebrates; the only other food item noted was a large earthworm. Most observations were during the morning, between 08 hoo and $12 \mathrm{hoo}$, but birds were twice flushed in the late afternoon.

This species is noted as occurring mainly in the north-east and centre of the rainforest belt, although it has also been recorded from Andohahela RNI 11 in the south-east (Collar and Stuart 1985). Langrand (1990) regards it as the most localized of the four rainforest ground-rollers, but reports that it is known from the proposed Mananara Biosphere Reserve to the north of Ambatovaky. It was seen almost daily on the Masoala peninsula in October 1980 (B.-U. Meyburg in 
Collar and Stuart 1985), which is the only other report of a sighting rate as frequent as that found in Ambatovaky. It is notable that the type-locality is the "Soamianina" river (Collar and Stuart 1985, who also give synonyms of "Semiang" or "Tsimianona", but the most recent maps give "Simianona"), opposite Nosy Borah (Isle St Marie): at its nearest point this river runs only $20 \mathrm{~km}$ to the north-east of Site 2 in Ambatovaky reserve.

Observations at Ambatovaky suggest that the general lack of records of this species in Madagascar may genuinely reflect its scarcity. Although its habits could make it easily overlooked (Turner 1984), in practice observers should encounter it readily enough in prime habitat. The areas favoured in Ambatovaky were at low altitude in primary rainforest with damp soils (valleys and ridge slopes) and moderate undergrowth, the particular sites happening to be one of the most threatened habitats in the reserve, most similar areas having already been cleared.

Near-threatened

Only one individual was recorded, separately by two observers at the same place, on 18 March 1990 at Site 2 along a ridge-top at approximately $425 \mathrm{~m}$. The bird was elusive, being flushed from close to a trail and flying a short distance downslope where it perched briefly on a horizontal log, and the second time landed part-hidden among dense undergrowth. It was in tail moult with the outermost tail-feathers only half-grown. This species, categorized as nearthreatened (Collar and Stuart 1985), is regarded as the commonest and most widely distributed of the ground-rollers (Langrand 1990). However, it would appear to be relatively scarce in Ambatovaky given the numbers of observations of other ground-rollers and other terrestrial birds. This relative status was confirmed by one knowledgeable person in Vatomora who, unprompted, reported that three species of ground-roller were present in the area, and, identifying them through the illustrations in Milon et al. (1973), indicated this species to be the scarcest.

\section{Grey-crowned Greenbul Phyllastrephus cinereiceps}

Rare

Only recorded on two occasions, both in mixed-species flocks at the intergrade between the moist montane and sclerophyllous montane forest zones at Site 1. On 21 February one was observed at approximately $900 \mathrm{~m}$, and on 25 February a group of at least four were at $950 \mathrm{~m}$ in very mossy and rather stunted $10-12 \mathrm{~m}$ high forest. Other flock members (from both flocks) included Long-billed and Short-billed Greenbuls Phyllastrephus madagascariensis and $P$. zosterops, Red-tailed Vanga Calicalicus madagascariensis, Madagascar Paradise Flycatcher Terpsiphone mutata, Dark and Common Newtonia Newtonia amphichroa and N. brunneicauda, and Souimanga and Green Sunbird Nectarinia souimanga and N. notata. In both cases the greenbuls were actively foraging by gleaning from the trunks of trees; they flew from tree-trunk to tree-trunk with strong, undulating flight, landing near the base and creeping up the vertical, moss-covered trunks (average diameter at breast height $15 \mathrm{~cm}$ ) for 5-15 seconds before moving on. Overall behaviour seemed volatile and highly active. 
In the second flock the birds kept up a near-continuous calling of insistent trills, similar to the calls of Short-billed Greenbul but "drier" and more insectlike. The bill looked notably shorter compared to that of Short-billed Greenbul. The birds appeared to be unused to man, flying over to investigate, perching openly only $4 \mathrm{~m}$ away and staring directly at the observer for 5-10 seconds, first with one eye then the other, before moving off. Similar inquisitive behaviour was shown by Red-tailed Vanga and Madagascar Paradise Flycatcher in the same flock; no alarm calls were given.

Habitat and foraging behaviour accord with recent observations at Marojejy (Safford and Duckworth 1990). It now seems clear that this species inhabits higher altitude rainforest. Recent records have been from the north-eastern rainforest, from Tsaratanana to Sihanaka forest (Collar and Stuart 1985). Ambatovaky is only the third reserve from which this species has been reported.

Near-threatened

Only one record of a flock of ten (the largest group) was noted at Site 1 , but this species was regularly seen at site 2 (19 records from eight days), all but one bird being in mixed-species flocks. The usual foraging behaviour was to glean from large leaves, mainly palm Vonitra sp., Pandanus sp. (a preference also noted by Langrand 1990), and dead leaves of palms and Ravenala madagascariensis, thoroughly investigating the undersides and rolled up parts of the leaves and also the crowns of the plants in their search for arthropods. Out of 12 feeding actions noted eight were on live fronds, three on dead fronds, and one was on the trunk of a large tree. By comparison, both feeding niches (fronds and trunks) were noted at Zahamena RNI (Thompson et al. 1987), but trunks and large branches appeared to be preferred, possibly because palms (but not Pandanus) were less common at mid-altitude $(850-950 \mathrm{~m})$. One caught a sizeable cricket, mandibulating and crunching it up in its bill before swallowing it. A pair foraging on palm fronds were twice chased off by a Blue Coua Coua caerulea, and on 15 March a group of Helmetbirds kept close to two females/juveniles, one juvenile Helmetbird paying particular attention. However, there appeared to be no clear association between the two species over and above the general tendency of large vanga species to occur together (see Dee 1986).

Although no scarcer than several other species of vanga at Site 2, its apparently specialized feeding requirements could put the Ambatovaky population at more risk than other rainforest-dependent vanga species, since collection of palm hearts occurs deep within the reserve.

\section{Helmetbird (Helmet Vanga) Euryceros prevostii}

The second most frequently recorded vanga in Ambatovaky (after Red-tailed Vanga), although this may not reflect true abundance; it was much more frequently recorded at Site 2 compared with Site 1 . At Site 1 it was only recorded at mid-altitude, mainly $800-900 \mathrm{~m}$, although it is generally regarded as preferring lower altitudes.

Family parties were seen from 22 February onwards, always in mixed-species flocks. The first juvenile on 22 February was free-flying but still begging (shiver- 
ing wings and opening bill). All but one sighting at Site 2 probably referred to one family party, consisting of an adult pair with three non-begging juveniles. A juvenile on 19 March caught a large Gasteracantha spider, which it crushed once with its bill, then swallowed whole. There were single observations of "flycatching" in mid-air and of sally-gleaning, while one juvenile was seen using its bill effectively to rip dead bark off a branch. Birds tended to perch on branches in the mid-storey but to forage in the shrub layer up to $7 \mathrm{~m}$ in height. Both this species and Bernier's Vanga are regarded as "particularly vulnerable" by Langrand (1990) because they are restricted to the north-east, so Ambatovaky is an important protected area for them both, although they are found as far south as Analamazaotra-Périnet Special Reserve (Langrand 1990).

Rand's Warbler Randia pseudozosterops

Near-threatened

Only recorded at Site 1: on 16 February one was in a mixed-species flock high in the canopy of tall primary lowland rainforest at $650 \mathrm{~m}$; and on 21 February in moist montane forest at $900 \mathrm{~m}$ another was in a large mixed-species flock. On both occasions the birds were gleaning on larger branches in the canopy, as noted in Zahamena (Thompson et al. 1987). Although its preference for the canopy makes it difficult to observe, the scarcity of records of this species is probably linked to its altitude preference, given as 800-1,500 $\mathrm{m}$ in Dee (1986): relatively little time was spent in forest in this altitude range.

Indeterminate

Two were seen in a mixed-species flock on 14 February and one in a mixedspecies flock on 23 February, about $500 \mathrm{~m}$ away from the first sighting. Both records were at approximately $700 \mathrm{~m}$ in primary lowland forest at Site 1 . Full details of the observations and descriptions are given in Evans (1991).

This species was known from only one specimen collected in 1931, and was a candidate for treatment as extinct. The validity of the taxon had even been disputed (for discussion see Collar and Stuart 1985). The species was rediscovered near Andohahela RNI in south-east Madagascar in late 1989 (Goodman and Schulenberg 1991), hence Ambatovaky forms only the third known site for this species (but all forest has now been cleared from the type-locality). Although it is probably difficult to detect in the forest canopy, Goodman and Schulenberg (1991) give details of a distinctive song, so the lack of records from recent intensive fieldwork suggests that it may genuinely be rare or absent from other areas surveyed. Its presence in the mid-altitude area of Ambatovaky strengthens the case for protection of the forest between Ranomena II and Iampirano (which is also where the dead Madagascar Serpent-eagle was found).

\section{Discussion}

One surprising absence at Site 1 was that of larger terrestrial birds - Redbreasted Coua, ground-rollers and mesites. It is possible that these species were in post-breeding moult during February when Site $I$ was surveyed and thus were even shyer than usual. It seems unlikely that such birds were absent since 
Site 1 is within their known altitudinal and habitat ranges. Other explanatory factors might be the differences in altitude and habitat structure between the two study sites (see Methods for description).

The two restricted-range vanga species were both found in mixed-species flocks mainly at Site 2, which may reflect either the gradual formation of postbreeding flocks (which are more easily detected than individuals) during the survey period, or higher abundance away from the wet valley forest of Site 1 (some large mixed-species flocks were encountered on mid-altitude ridges at Site 1 ), or both. The wet valley forests at Site 1 had a higher canopy with fewer midstorey trees, and the presence of the latter is probably important to these larger vangas given their feeding behaviour.

Seven threatened rainforest bird species and five near-threatened species were not recorded in Ambatovaky. Most of these are species which are very difficult to detect. One surprising absence was Ward's Flycatcher Pseudobias wardi (near-threatened), listed as common by Langrand (1990) and found to be common in Zahamena RNI (Thompson et al. 1987), but which probably prefers higher altitudes and habitat zones. Ambatovaky is the closest sizeable area of extant rainforest to, and is directly west of, Nosy Borah where the Snail-eating Coua Coua delalandei, treated as extinct though with a marginal possibility of being extant by Collar and Stuart (1985), was last (and perhaps only ever) recorded. During discussions with local people about the birds of the reserve photographs of a specimen from the British Natural History Museum were shown, but this species was not recognized; it seems unlikely to occur in the reserve or to survive anywhere.

Langrand (1990) notes that the eastern rainforest region of Madagascar possesses the most diverse resident avifauna in Madagascar, and that 36 species (one a non-endemic) are restricted to this region and hence are potentially vulnerable to loss of rainforest; of these, $23(64 \%)$ were definitely recorded in Ambatovaky. Out of these 36 forest species, those listed as threatened or nearthreatened in Collar and Stuart (1985) are clearly of particular note. Given that this study recorded seven threatened rainforest species - two of them (Madagascar Serpent-eagle and Red-tailed Newtonia) being amongst the very rarest and one (White-breasted Mesite) representing an astonishing range-extension along with five near-threatened species, Ambatovaky is of obvious importance to conservation.

Langrand (1990) also identifies four species - Red-breasted Coua, Scaly Ground-roller, Bernier's Vanga and Helmetbird - as being "particularly vulnerable" because they are restricted to rainforest in the north-east of the island; all four were found to be relatively numerous in Ambatovaky, particularly at Site 2, and all appear to be primarily lowland rainforest species. The vital importance of Ambatovaky, which contains $54 \%$ of all the Lowland or Eastern Domain rainforest currently held within the existing protected area system in Madagascar (Langrand 1990), is thus confirmed.

Collar and Stuart (1988) developed a scoring system for ranking the known ornithological importance of Afro-Malagasy region forests, based on the occurrence of threatened and near-threatened species. Based on this system, Ambatovaky would rank as equal eleventh for ornithological conservation priorities in terms of Afro-Malagasy region forests. However, we are sure that more 
species of bird - including threatened and near-threatened forms - remain to be discovered in Ambatovaky, given the briefness of this survey, and that its conservation importance will only increase over time.

Amongst the threatened species, three stand out as of particular significance. (1) The White-breasted Mesite, previously believed to be restricted to the deciduous forest of western Madagascar, makes Ambatovaky a unique site where two of the three species in the endemic Mesitornithidae family are sympatric. (2) The dead Madagascar Serpent-eagle found near Site 1 is the first specimen found since 1930 and gives material evidence of the continued existence of a species, which is one of the world's rarest and least known birds of prey. (3) The two sightings of Red-tailed Newtonia make the reserve only the second existing site in the world for a species known until 1989 from only one specimen. Both the lowland rainforest and montane forest of Ambatovaky are of vital importance, since the last two species came from the western part of the reserve at the ecotone between the two forest types, and there is potential to expand the reserve in this area.

For Ambatovaky there is currently protection in name only: there are no forest guards assigned to protect the reserve and local people are unaware of any restrictions on use of the forest. It is essential that further clearance of lowland rainforest (such as at Site 2) be halted, but this can only proceed with the agreement and cooperation of the local people, and with measures to protect their livelihoods. A survey of the local communities and remainder of the reserve boundary areas is needed. In re-designating the boundary some nowdeforested areas could be left out while substantial additional areas of primary forest to the west and south could be given protection. Sympathetic enforcement of a newly designated reserve will then be necessary.

Conserving the rainforest of Ambatovaky would significantly help to maintain the diversity of endemic Malagasy birds, and would help to protect at least 12 threatened and near-threatened species. The reserve contains the largest area of lowland rainforest in Madagascar's reserve system, and is one of the few remaining such areas where viable populations of species preferring this habitat may survive. Moreover, it is to be noted that the expedition also made very exciting finds amongst other animal groups (Thompson and Evans 1991b). Eighty-six reptile and amphibian species were recorded in the reserve, comprising the most diverse herpetofaunal community yet known in Madagascar. Twelve per cent of the herpetofauna (10 species) are thought to be new to science, and are so far only known from Ambatovaky. At least 11 primate species occur within the reserve, as well as a shrew-tenrec Microgale new to science (P. Jenkins, British Natural History Museum, verbally 1991).

\section{Acknowledgements}

This expedition was organized by the Madagascar Environmental Research Group and was sponsored by: the Loke Wan Tho Memorial Foundation, an International Council for Bird Preservation - Fauna and Flora Preservation Society 1989 expedition competition award, the Royal Geographical Society, Gilchrist Educational Trust, The Conservation Foundation, Elmgrant Trust, Percy Sladen Trust, the British Ornithologists' Union, British Museum (Natural History), Aldeburgh, Leiston and Saxmundham Lions Club, 
Rotary Club of Saxmundham and District, and the A. S. Butler Trust. The other team members all contributed observations of birds and to the general success of the expedition: T. Barden, J.-B. Ramanamanjato, A. Raselimanana, C. J. Raxworthy, J.-C. Razafimahaimodison, and A. Wilson. We also thank our local guides and the people of lampirano, Amberomanitra and Vatomora for sharing with us their knowledge of Ambatovaky's birds. Olivier Langrand provided advice on identifications and status, and we would also like to thank M. Nicoll, N. Quansah, F. Rakotondraparany and P. J. Stephenson for their help in Madagascar. P. R. Colston of the British Natural History Museum identified the Madagascar Serpent-eagle material, and allowed access to the collections. We thank especially the Ministère de l'Enseignement Supérieure, the Direction des Eaux et Forêts (Service de la Protection de la Nature), and the Ministère de la Recherche Scientifique et Technologique pour le Développement for their approval and support for this expedition.

\section{References}

Benson, C. W. (1981) Les oiseaux: des espèces unique au monde. Pp.63-74 in P. Oberlé, ed., Madagascar: un sanctuaire de la nature. Antananarivo: Kintana.

Benson, C. W., Colebrook-Robjent, J. F. R. and Williams, A. (1976-1977) Contribution à l'ornithologie de Madagascar. Oiseau et R.F.O. 46: 103-134, 209-242, 367-386; 47: 41-64, 167-191.

Collar, N. J. and Andrew, P. (1988) Birds to watch: the ICBP world checklist of threatened birds. Cambridge, U.K.: International Council for Bird Preservation.

Collar, N. J. and Stuart, S. N. (1985) Threatened birds of Africa and related islands: the ICBP/ IUCN red data book. Third edition, Part 1. Cambridge, U.K.: International Council for Bird Preservation.

Collar, N. J. and Stuart, S. N. (1988) Key forests for threatened birds in Africa. Cambridge, U.K.: International Council for Bird Preservation (ICBP Monograph 3).

Dee, T. J. (1986) The endemic birds of Madagascar. Cambridge, U.K.: International Council for Bird Preservation.

Evans, M. I. (1991) The Red-tailed Newtonia Newtonia fanovanae in the Ambatovaky Reserve, north-east Madagascar. Bird Conserv. Internatn. 1: 47-52.

Evans, M. I. and Raxworthy, C. J. (in prep.). An extraordinary record of White-breasted Mesite Mesitornis variegata from Ambatovaky Special Reserve, Madagascar.

Goodman, S. M. and Schulenberg, T. S. (1991) The rediscovery of the Red-tailed Newtonia Newtonia fanovanae in south-eastern Madagascar with notes on the natural history of the genus Newtonia. Bird Conserv. Internatn. 1: 33-45.

Green, G. M. and Sussman, R. W. (1990) Deforestation history of the eastern rain torests of Madagascar from satellite images. Science 248: 212-215.

Hawkins, A. F. A., Chapman, P., Ganzhorn, J. U., Bloxham, Q. M. C., Barlow, S. C., and Tonge, S. J. (1990) Vertebrate conservation in Ankarana Special Reserve, northern Madagascar. Biol. Conserv. 54: 83-110.

Jenkins, M. D., ed. (1987) Madagascar, an environmental profile. Gland, Switzerland: IUCN/ UNEP/WWF.

Keith, S., Forbes-Watson, A. D. and Turner, D. A. (1974) The Madagascar Crested Ibis, a threatened species in an endemic and endangered avifauna. Wilson Bull. 86: 197-199.

Langrand, O. (1990) A guide to the birds of Madagascar. New Haven and London: Yale University Press.

Langrand, O. and Meyburg B.-U. (1984) Birds of prey and owls in Madagascar; their distribution, status and conservation. Pp.3-13 in J. M. Mendelsohn and C. W. Sapsford, eds. Proceedings of the Second Symposium on African predatory birds, 22-26 August 1983. Durban: Natal Bird Club. 
Millon, P., Petter, J.-J. and Randrianasolo, G. (1973) Oiseaux. Faune de Madagascar 35. Tananarive and Paris: ORSTOM and CNRS.

Morony, J. J., Bock, W. J. and Farrand, J. (1975) Reference list of the birds of the world. New York: American Museum of Natural History (Department of Ornithology).

Nicoll, M. E. and Langrand, O. (1989) Madagascar: revue de la conservation et des aires protégées. Gland, Switzerland: World Wide Fund for Nature.

Rand, A. L. (1936) The distribution and habits of Madagascar birds. Bull. Amer. Mus. Nat. Hist. 72: 143-499.

Raxworthy, C. J. and Colston, P. R. (1992) Conclusive evidence for the continuing existence of the Madagascar Serpent-eagle Eutriorchis astur. Bull. Brit. Orn. Club 112: 108-111.

Safford, R. and Duckworth, W., eds. (1990) A wildlife survey of Marojejy Nature Reserve, Madagascar. Cambridge, U.K.: International Council for Bird Preservation (ICBP Study Report 40).

Sheldon, B. C. and Duckworth, J. W. (1990) The rediscovery of the Madagascar Serpenteagle Eutriorchis astur. Bull. Brit. Orn. Club 110: 126-130.

Thompson, P. M. and Buisson, R. S. K. (1988) Birds of Manongarivo. Pp.87-120 in N. Quansah, ed. Manongarivo Special Reserve (Madagascar) 1987-88 expedition report. London: Madagascar Environmental Research Group.

Thompson, P. M. and Evans, M. I. (1991a) The birds of Ambatovaky. Chapter 4 in P. M. Thompson and M. I. Evans, eds. A survey of Ambatovaky Special Reserve, Madagascar. London: Madagascar Environmental Research Group.

Thompson, P. M. and Evans, M. I., eds. (1991b) A survey of Ambatovaky Special Reserve, Madagascar. London: Madagascar Environmental Research Group.

Thompson, P. M., Raxworthy, C. J., Quansah, N., Murdoch, D. A. and Stephenson, P. J. (1987) Zahamena Forest (Madagascar) Expedition 1985. Cambridge, U.K.: International Council for Bird Preservation (ICBP Study Report 20).

Turner, D. A. (1984) The ground-rollers of Madagascar. Pp.553-557 in J. Ledger, ed. Proceedings of 5 th Pan-African Ornithological Congress. Johannesburg: Southern African Ornithological Society.

White, F. (1983) The vegetation of Africa. A descriptive memoir to accompany the Unescol AETFAT/UNSO vegetation map of Africa. Paris: Unesco (Natural Resources Research 20).

Whitmore, T. C. (1984) Tropical rain forests of the Far East. Second edition. Oxford: Clarendon.

PAUL M. THOMPSON

Middlesex University, Queensway, Enfield EN3 4 SF, U.K.

MICHAEL I. EVANS

Montrose, Llanddeiniol, Llanrhystud, Dyfed SY23 5 AN, U.K. 